Hydrology and Earth System Sciences, 8(3), 533-544 (2004) C EGU

\title{
Impacts of forestry on nitrogen in upland and lowland catchments: a comparison of the River Severn at Plynlimon in mid-Wales and the Bedford Ouse in south-east England using the INCA Model
}

\author{
P.G. Whitehead ${ }^{1}$, T.J. Hill ${ }^{1}$ and C. Neal ${ }^{2}$ \\ ${ }^{1}$ Aquatic Environment Research Centre, Department of Geography, University of Reading, Whiteknights, Reading, RG6 6AB, UK \\ ${ }^{2}$ Centre for Ecology and Hydrology, Wallingford, OX10 8BB, UK \\ Email for corresponding author: p.g.whitehead@reading.ac.uk
}

\begin{abstract}
The impacts of afforestation at Plynlimon in the Severn catchment, mid-Wales, and in the Bedford Ouse catchment in south-east England are evaluated using the INCA model to simulate Nitrogen $(\mathrm{N})$ fluxes and concentrations. The INCA model represents the key hydrological and N processes operating in catchments and simulates the daily dynamic behaviour as well as the annual fluxes. INCA has been applied to five years of data from the Hafren and Hore headwater sub-catchments $\left(6.8 \mathrm{~km}^{2}\right.$ area in total $)$ of the River Severn at Plynlimon and the model was calibrated and validated against field data. Simulation of afforestation is achieved by altering the uptake rate parameters in the model. INCA simulates the daily $\mathrm{N}$ behaviour in the catchments with good accuracy as well as reconstructing the annual budgets for $\mathrm{N}$ release following clearfelling; a four-fold increase in N fluxes was followed by a slow recovery after re-afforestation. For comparison, INCA has been applied to the large $\left(8380 \mathrm{~km}^{2}\right)$ Bedford Ouse catchment to investigate the impact of replacing $20 \%$ arable land with forestry. The reduction in fertiliser inputs from arable farming and the $\mathrm{N}$ uptake by the forest are predicted to reduce the $\mathrm{N}$ flux reaching the main river system, leading to a $33 \%$ reduction in N-Nitrate concentrations in the river water.
\end{abstract}

Keywords: afforestation, water quality, nitrogen, modelling, land-use change, Wales, Plynlimon, Hore, Hafren, Bedford Ouse, Severn

\section{Introduction}

Many types of pollution have detrimental effects on the environment and nitrogen, in particular, enhances acidification in the uplands and eutrophication in the lowlands. Nitrogen $(\mathrm{N})$ processes in upland hydrological systems are significant because nitrogen transformation can cause more acidification than sulphur deposition or base cation uptake by vegetation (Stevens, et al., 1994). Many forests in Europe may be regarded as nitrogen saturated, with leaching of $\mathrm{N}$ in excess of plant and microbial demands potentially causing problems of water potability and eutrophication (Wilson and Emmett, 1999; Dise and Wright, 1995). In lowland catchments across Europe, high $\mathrm{N}$ concentrations in streams and groundwaters can exceed the EU limit of $11.3 \mathrm{mg}-\mathrm{N}^{-1}$ for public water supply. Thus, nitrogen management, policy controls and planned reductions are key drivers for government agencies and water companies. In upland forested catchments, fertiliser application is rare, yet atmospheric inputs may become a dominant source of nitrogen in surface waters (Whitehead et al., 1998a, b). Other important contributions of nitrogen to upland and lowland surface waters occur directly from the soil and vegetation biomass, which is a very substantial store of nitrogen. The relative significance of the individual sources and the mechanisms of nitrogen production may vary considerably, both spatially and temporally. Modelling techniques facilitate full assessment of the processes and prediction of the impacts associated with changes in atmospheric deposition, land-use change and vegetative uptake.

In this paper, issues relating to the dynamics of nitrogen in upland and lowland catchments are addressed; in 
particular, the effects of afforestation on $\mathrm{N}$ fluxes and $\mathrm{N}$ concentrations in streams are evaluated. The dynamics of $\mathrm{N}$ are examined using a semi-distributed, processes-based modelling approach, INCA (Whitehead et al., 1998a,b; Wade et al., 2002) and predictions are compared with field measurements. An evaluation of the INCA model in upland and lowland catchments validates the model in situations where afforestation effects are either significant at the present time or could be significant in the future.

\section{The INCA model}

The INCA model (Whitehead et al., 1998a,b; Wade et al., 2002) has been designed to investigate the fate of nitrogen in both aquatic and terrestrial environments. The model incorporates both dynamic and stochastic elements and is semi-distributed, with nitrogen fluxes produced as daily time series, outputs assessed as either probabilistic or percentile values and spatial variations in land-use categorised into land-use classes. The model has five main components: a GIS interface, a nitrogen input model, a hydrological model, a catchment nitrogen process model and a river nitrogen process model (Whitehead et al., 1998a). A semi-distributed GIS interface is used in INCA to represent percentage changes in land-use cover, together with a land classification scheme based on a simplified version of the Centre for Ecology and Hydrology (CEH) Land cover map of Great
Britain, using six land classes following the study of Whitehead et al. (1998a). MORECS soil moisture and evaporation data are used to calculate daily Hydrologically Effective Rainfall (HER). Hydrology is simulated using a simple two-box model with soil- and ground-water components: each river reach is then modelled using a massbalance approach to inputs, storage and outflow. Catchment nitrogen process mass balance differential equations in the soil- and ground-water are solved simultaneously with the equations of flow.

Figure 1 shows the principal sources, sinks and transformation processes that affect $\mathrm{N}$ in upland and lowland systems. Deposition of N can be supplemented by fertilizer applications and fixation of $\mathrm{N}$ from the atmosphere; within the soils, $\mathrm{N}$ can also be generated by mineralisation of organic $\mathrm{N}$ to create a pool of ammoniacal $\mathrm{N}$ which is then subject to microbially controlled reactions that nitrify the ammonium to nitrate N. Other microbial processes can convert this Nitrate $\mathrm{N}$ to nitrogen gas and nitrous oxide during a denitrification stage. All of these processes in the soils are controlled by temperature and soil moisture conditions which will vary on a day to day basis. In addition, $\mathrm{N}$ will be removed from the soil pools by vegetative growth and will be lost to both groundwaters and streams as water moves through the system. Even the $\mathrm{N}$ in the groundwaters cannot be considered to be a stable pool as this $\mathrm{N}$ will be lost eventually to the rivers as groundwater baseflow. Thus,

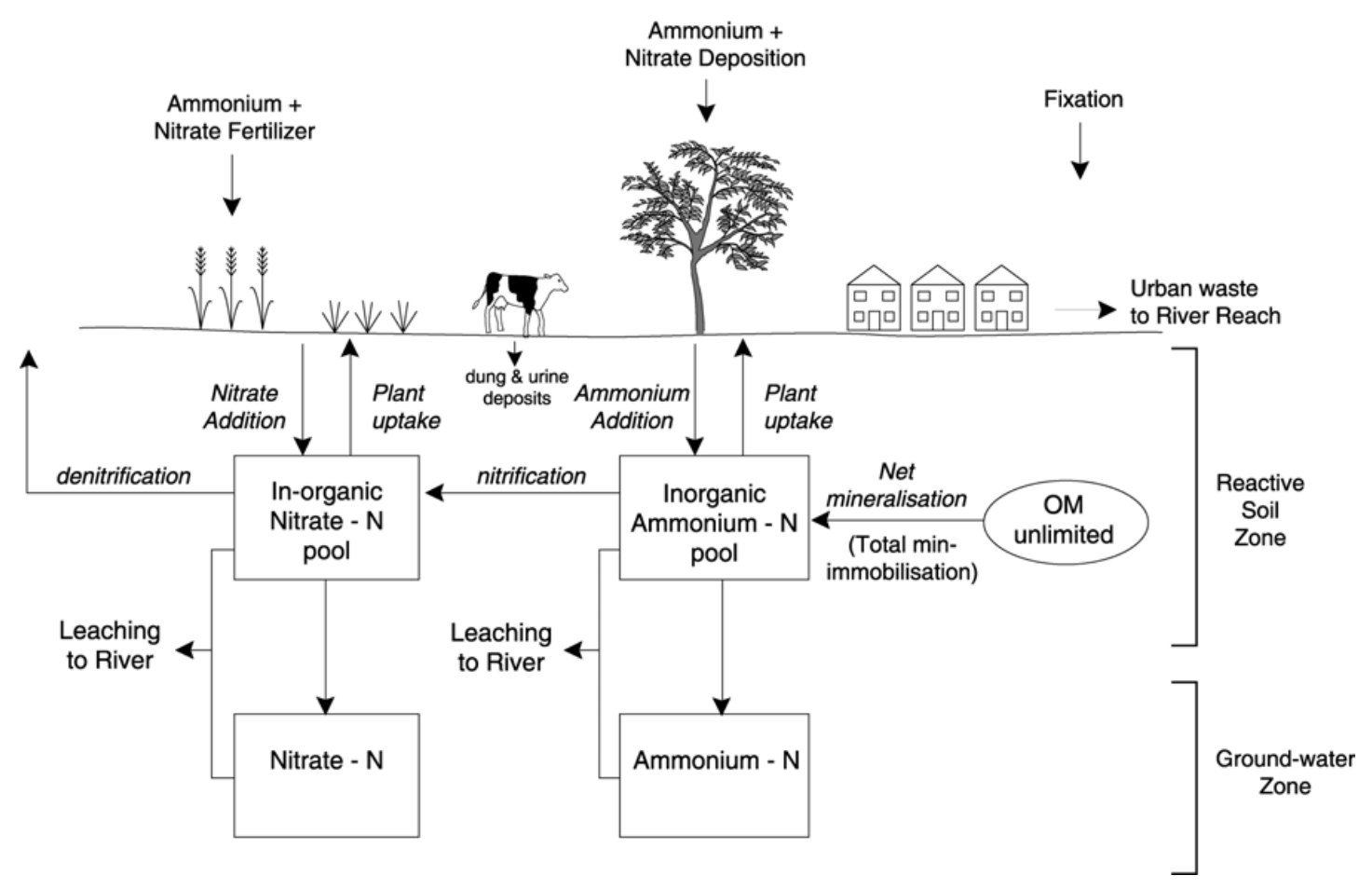

Fig. 1. The INCA nitrogen sources, sinks, processes and flowpaths 
the $\mathrm{N}$ cycle is complex with processes interacting to create complex patterns of behaviour.

The important processes affecting the transformation of nitrogen are represented for both $\mathrm{NO}_{3}-\mathrm{N}$ and $\mathrm{NH}_{4}-\mathrm{N}$ by the equations:

$$
\mathrm{NO}_{3}-\mathrm{N}
$$

\section{Soil water Zone}

$\frac{d x_{3}}{d t}=\frac{1}{V_{1}}\left(U_{3}-x_{1} x_{3}\right)-C_{3} U_{7} x_{3}+C_{6} x_{5}-C_{1} U_{5} x_{3}+C_{2}$

\section{Groundwater Zone}

$$
\frac{d x_{4}}{d t}=\frac{1}{V_{2}}\left(x_{3} x_{1} U_{8}-x_{2} x_{4}\right)
$$

$\mathrm{NH}_{4}-\mathrm{N}$

\section{Soil water Zone}

$$
\frac{d x_{5}}{d t}=\frac{1}{V_{1}}\left(U_{4}-x_{1} x_{5}\right)-C_{10} U_{7} x_{5}+C_{6} x_{5}-C_{7} U_{6}+C_{8} x_{5}
$$

\section{Groundwater Zone}

$$
\frac{d x_{6}}{d t}=\frac{1}{V_{2}}\left(x_{5} x_{1} U_{8}-x_{2} x_{6}\right)
$$

where $x_{3}$ and $x_{4}$ are the daily $\mathrm{NO}_{3}-\mathrm{N}$ concentrations (mg$\mathrm{N}^{-1}$ ), and $x_{5}$ and $x_{6}$ are the daily $\mathrm{NH}_{4}-\mathrm{N}$ concentrations $\left(\mathrm{mg}-\mathrm{N}^{-1}\right)$, in the soil- and ground-water zones respectively. The values $V_{1}$ and $V_{2}$ are the equivalent water volumes for the soil- and ground-water zones, related to the respective mean flow. $U_{s}$ is the baseflow index. Daily rate coefficients for plant uptake of $\mathrm{NO}_{3}$, nitrification, denitrification, biological fixation, plant uptake of $\mathrm{NH}_{4}$, mineralisation and immobilisation are expressed by $C_{3}, C_{6}, C_{1}, C_{2}, C_{10}, C_{7}$ and $C_{8}$ respectively. All rate coefficients are temperature dependent according to the equation,

$$
C_{n}(\theta \mathrm{S})=C_{n}(20) 1.047^{\left(\theta_{s}-20\right)}
$$

Where, $\theta_{\mathrm{s}}$ is soil temperature estimated from a seasonal relationship based on air temperature. Plant uptake, for both $\mathrm{NO}_{3}-\mathrm{N}$ and $\mathrm{NH}_{4}-\mathrm{N}$ is determined by the availability of nitrate and ammonium, the daily uptake rate and a seasonal plant growth index. The user can specify maximum uptake rates and the length of the growing season. The mineralisation and immobilisation of $\mathrm{N}$ is dependent upon the rate, the concentration and the soil moisture conditions. No account is taken of litterfall and it is assumed that mineralisation is not limited by organic matter availability. Nitrification is estimated from the daily nitrification rate and the concentration of ammonium. The model uses a threshold, determined by the user, as to when denitrification occurs depending upon the soil moisture conditions. Nitrogen fixation from the atmosphere is assumed to be at a fixed rate. Nitrogen processes in the river system are simulated using the mass-balance equations:

Flow

$$
\frac{d x_{7}}{d t}=\frac{1}{T_{3}}\left(U_{9}-x_{7}\right)
$$

$$
\begin{aligned}
& \mathrm{NO}_{3}-\mathrm{N} \\
& \left.\qquad \frac{d x_{8}}{d t}=\frac{1}{V_{3}}\left(U_{10} U_{9}-x_{7} x_{8}\right)-C_{17} x_{8}+C_{14} x_{9}\right) \\
& \mathrm{NH}_{4}-\mathrm{N} \\
& \qquad \frac{d x_{9}}{d t}=\frac{1}{V_{3}}\left(U_{11} U_{9}-x_{7} x_{9}\right)-C_{14} U_{3} x_{9} \\
& \text { where } \\
& \text { and } \quad V_{3}=T_{3} x_{3} \\
& \qquad T_{3}=\frac{L}{v}=\frac{L}{a Q^{b}}
\end{aligned}
$$

In Eqns. 6-10, $T_{3}$ is the residence time in the reach, $U_{9}$ is the sum of the upstream flows, sub-catchment run-off and sewage discharge. $U_{10}$ and $U_{11}$ are the flow-weighted $\mathrm{NO}_{3}-\mathrm{N}$ and flow-weighted $\mathrm{NH}_{4}-\mathrm{N}$, respectively, based on their concentrations upstream. The estimated downstream flow rate is expressed as $x_{7}$ and concentrations of nitrate and ammonium are $\mathrm{x}_{8}$ and $\mathrm{x}_{9}$, respectively. The parameters for denitrification and nitrification $\left(C_{17}\right.$ and $\left.C_{14}\right)$ are temperature dependent. The structure of the model is multireach and mass balance equations are solved within each reach. Additional inputs and outputs from abstractions, subcatchment inflows and effluent discharges are incorporated in these calculations. The differential equations are solved using 4th order Runge Kutta integration, with a Merson variable step length for accuracy and speed of computation.

The INCA model has been applied to a variety of UK catchments, including the Rivers Tywi (Whitehead et al., 1998b), Dee (Wade et al., 2001), Kennet (Whitehead et al., 2002), Tweed (Jarvie et al., 2002) and Lee (Flynn et al., 2002). In Europe, the model has been applied extensively as shown in Hydrology and Earth System Sciences Special Issue, devoted to INCA research (Neal (Ed.), 2002a). INCA was successful in reproducing patterns of nitrogen behaviour, accounting for changes in land-use, hydrology 
and deposition, and providing a suitable modelling framework to investigate nitrogen dynamics in these catchments.

\section{Estimating $\mathbf{N}$ depostion across the UK}

A key requirement of the INCA model is an estimate of the $\mathrm{N}$ deposition across the UK and in specific catchments. This has been achieved using a GIS approach applied to the outputs of atmospheric models combined with $\mathrm{N}$ deposition rates and land use across the UK.

The emission of nitrogen into the atmosphere from the UK is known to be substantial, historically around 700000 tonnes a year of $\mathrm{NO}_{\mathrm{x}}$, as $\mathrm{N}$, between 1970 and 1985. Since then, reductions in industrial emissions have been offset by an increase in vehicle use and road transport. International agreements and targets set by the Sofia Protocol (Skeffington, 2002) have been met by the UK limiting national nitrogen oxide emissions to 1987 levels. Yet, in 1994, the total emissions were still 675000 tonnes- $\mathrm{N} \mathrm{yr}{ }^{-1}$ of which $56 \%$ was derived from transport sources, $24 \%$ from electricity generation and $15.5 \%$ from other industrial sources (Skeffington, 2002). Thus, N emissions continue to be significant across the UK and, for any study of nitrogen in the uplands, the emission figures have to be converted into estimates of $\mathrm{N}$ deposition. This can be done using techniques such as long-range transport and deposition models. Three such models are MATADORN, HARM or TRACE (Metcalfe et al., 1998; Lee et al., 2000) and Fig. 2 shows a nitrogen deposition map of the UK generated by combining outputs from the MATADORN model with

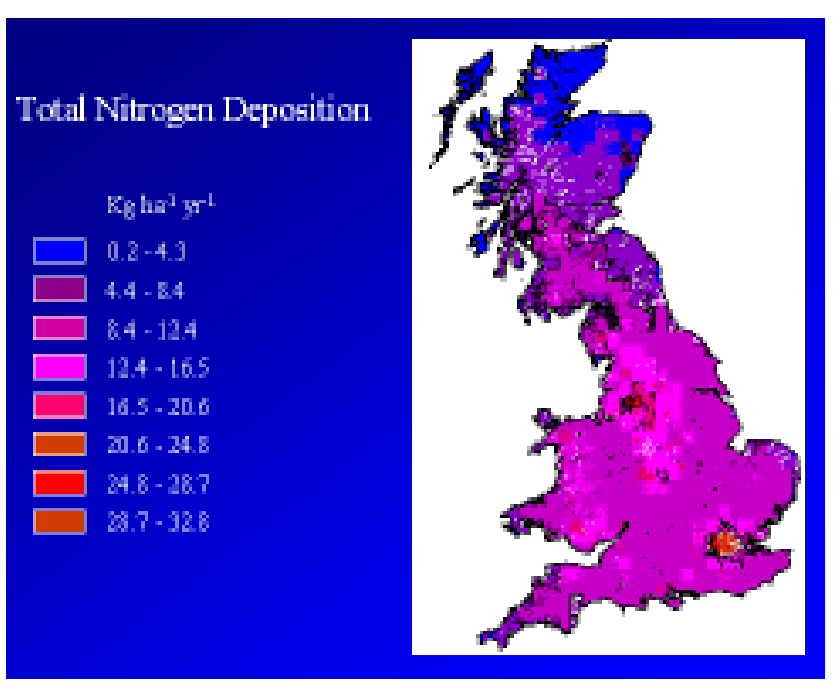

Fig. 2. Total $N$ deposition across the $U K$
NERC CEH Land-use Classification Data and N deposition velocities. From this figure and the GIS model, it is possible to estimate deposition in upland and lowland areas. For example, mid-Wales is shown to receive deposition of nitrogen at a rate between 12 and $16 \mathrm{~kg} \mathrm{~N}$ per hectare per year whereas, in south-eastern England, deposition is about 8-12 kg N ha ${ }^{-1} \mathrm{yr}^{-1}$.

\section{NITROGEN CHEMISTRY IN SOILS, STREAMS AND GROUND WATERS AT PLYNLIMON}

The Plynlimon experimental catchments comprise the headwaters of the River Wye with moorland and improved moorland and of the River Severn with mostly forest cover. This paper is concerned with the Severn, which has two major sub-catchments, the Hafren and the Hore (Fig. 3) at altitudes between $300 \mathrm{~m}$ and $750 \mathrm{~m}$ above sea level. The whole area is underlain by base-poor Lower Palaeozoic mudstones, shales and grits upon which a mosaic of acid upland soils has developed (Fig. 4). Underlying the soils in some parts of the catchment are drift deposits of boulder clay and colluvium derived from the bedrock. Most of the upper Severn catchment is covered in plantation forest consisting mainly of Sitka spruce (Picea sitchensis) and Norway spruce (Picea abies) planted in three phases between 1937 and 1964. Prior to planting, the catchment was drained extensively by ploughing and ditching. Parts of the catchment are now subject to second rotation/planting.

The Plynlimon experiment is one of the longest running catchment studies in Europe; catchment characteristics and

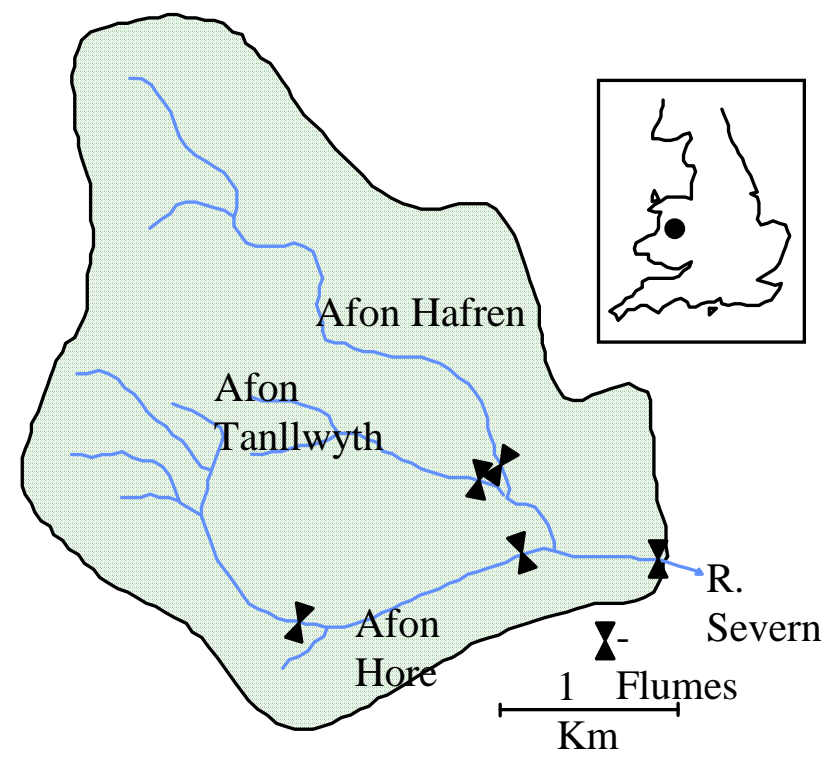

Fig. 3. The Severn catchment with the Hore and Hafren subcatchments 


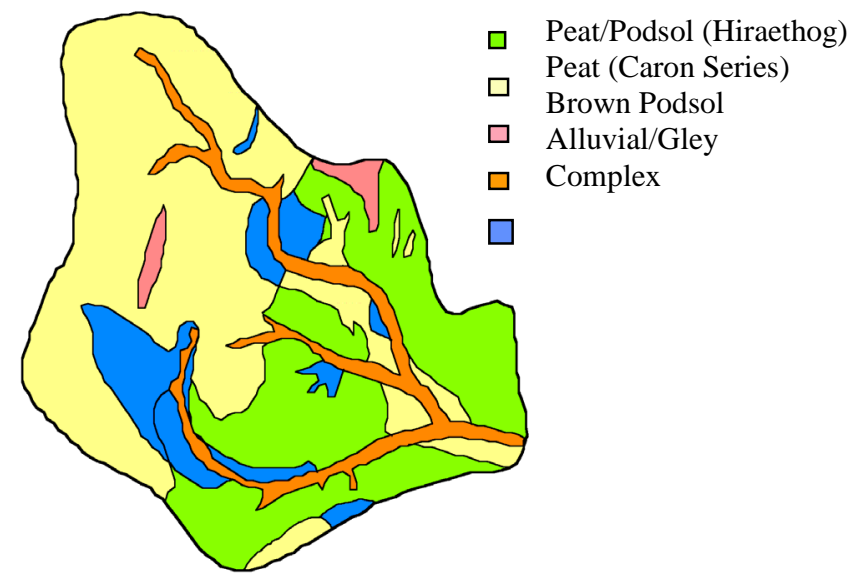

Fig. 4. Soil associations at Plynlimon

hydrochemical behaviour are documented in great detail in a Special Issue of Hydrology and Earth System Sciences dedicated to the Plynlimon catchments (Neal et al., 1997). Several acidification modelling studies have been sited at Plynlimon (Whitehead et al., 1988a,b; Robson et al., 1991; Neal et al., 1992b; Forti et al., 1996) based on the model MAGIC, developed by Cosby et al.(1985a,b), to investigate the impacts of sulphate deposition on soil and surface water chemistry (acidity). As with other chemical species analysed at Plynlimon, nitrogen has been investigated extensively with particular reference to the changes in deposition loads and land use and the effect on streamwater quality (Reynolds et al., 1992; Neal et al., 2003). The Severn catchment receives relatively high fluxes of nitrate and ammonium as wet aerosol and dry deposition and approximately $40 \%$ of the input is derived from dry and mist deposition (Neal et al., 1997). Concentrations of both $\mathrm{NO}_{3}{ }^{-}$and $\mathrm{NH}_{4}^{+}$are enhanced in dry and mist deposition, as shown in Table 1 (see also Wilkinson et al., 1997). In the Severn subcatchments, streamwater concentrations of $\mathrm{NO}_{3}{ }^{-}$and $\mathrm{NH}_{4}^{+}$ are relatively similar (Table 1). Groundwater concentrations of $\mathrm{NO}_{3}^{-}$are approximately half that in the streamwaters, although $\mathrm{NH}_{4}^{-}$concentrations are higher in the groundwater, possibly related to changes in mineralisation (Table 1). Neal et al., $(1997,2003)$ conclude that $\mathrm{NO}_{3}{ }^{-}$is retained slightly in the Hafren catchment and strongly in the Hore catchment, and $\mathrm{NH}_{4}{ }^{+}$is retained in all the sub-catchments.

Large temporal variability is observed in nitrate and ammonium concentrations. Stream waters in the Severn catchment exhibit a distinct seasonal pattern, with summer minima and winter maxima (Reynolds et al., 1992; Neal, et al., 1997). From April to June, the biological demand for $\mathrm{N}$ increases, with a subsequent decrease in concentrations in river waters. In late summer and autumn, the biological demand remains high but the process of mineralisation
Table 1. Mean Nitrogen in deposition, soil water, streamwater and groundwater. Mean values expressed in bold, with the range in parentheses. (Table adapted from Reynolds et al., 1988)

\begin{tabular}{lll}
\hline Site & $\mathrm{NO}_{3}^{-}-\mathrm{N}\left(\mathrm{mg} \mathrm{l}^{-1}\right) \mathrm{NH}_{4}^{+}-\mathrm{N}\left(\mathrm{mg} \mathrm{l} l^{-1}\right)$ \\
\hline Rainwater & $\mathbf{0 . 3 4}(0-2.89)$ & $\mathbf{0 . 4 0}(0-3.96)$ \\
Cloud Droplet & $\mathbf{5 . 2 3}(0.11-46.3)$ & $\mathbf{4 . 6 6}(0-41.93)$ \\
Soil Oh* & $\mathbf{0 . 1 8}(0.16-0.20)$ & $\mathbf{0 . 0 0}$ \\
Soil Eag* & $\mathbf{0 . 1 6}(0.11-0.20)$ & $\mathbf{0 . 0 0}$ \\
Soil Bs & \\
Soil C* & $\mathbf{0 . 0 1}(0-0.02)$ & $\mathbf{0 . 0 0}$ \\
Soil (Mean) & $\mathbf{0 . 2 2}(0.20-0.25)$ & $\mathbf{0 . 0 0}$ \\
Upper Hafren (Haf2) & $\mathbf{0 . 2 3}(0-1.04)$ & $\mathbf{0 . 0 1}(0-0.08)$ \\
Lower Hafren (Haf14) & $\mathbf{0 . 2 9}(0-1.36)$ & $\mathbf{0 . 0 1}(0-0.70)$ \\
Upper Hore (Hor1) & $\mathbf{0 . 2 2}(0.02-1.04)$ & $\mathbf{0 . 0 1}(0-0.23)$ \\
Lower Hore (Hor3) & $\mathbf{0 . 3 6}(0.05-1.06)$ & $\mathbf{0 . 0 1}(0-0.23)$ \\
Afon Tanllwyth (Tan7) & $\mathbf{0 . 5 4}(0.14-1.54)$ & $\mathbf{0 . 0 1}(0-0.23)$ \\
Groundwater (Mean) & $\mathbf{0 . 1 7}(0.02-0.29)$ & $\mathbf{0 . 0 4}(0-0.08)$ \\
\hline
\end{tabular}

results in streamwater $\mathrm{NO}_{3}^{-}$increasing erratically, depending on factors such as rainfall and temperature. In winter, the biological demand is small and, due to high throughputs of water, leaching of nitrate and ammonium into rivers occurs, (Reid et al., 1981; Neal, et al., 1997). This pattern of summer minima and winter maxima is repeated in the groundwater chemistry but, with more scatter, the relationship is less well defined.

\section{Application of INCA to the Plynlimon catchment}

The Hore and Hafren comprise a substantial proportion of the Severn catchment (Fig. 3). The area is/was primarily forested with coniferous woodland up to the tree line; a small area at the upper extent of each sub-catchment is seminatural moorland, grazed by sheep. The lower half of the Hore catchment was felled extensively between 1985 and 1989 while limited felling in the Hafren enables it to be used as a control. During and soon after the felling, $\mathrm{NO}_{3}^{-}$ concentrations were elevated but, thereafter, concentrations tended towards original levels and fluxes by 1992-1993, with further reductions as nitrogen was incorporated into the developing biomass (Neal, 2002a,b; Neal et al., 2003).

The first phase of the INCA application was calibration of the model to the Hafren for the year 1990 using several parameters, such as baseflow indices, derived from 
published data. Other parameters were adjusted to fit the observed chemical and hydrological data for 1990. There has been a significant effort on the estimation of the INCA model parameters with an error minimisation procedure adopted in the early applications (Whitehead et al., 1998b) and more sophisticated Monte Carlo approaches recently during the EU INCA project (Raat et al., 2003). During the INCA project, a consistent set of parameters was applied to a wide range of catchments across Europe and this set has been used in the Plynlimon application. The driving variables for INCA include hydrologically effective rainfall (HER), temperature and soil moisture deficit, as shown in Fig. 5, for the Afon Hafren stream for the years 1990 to 1994. The model output for this period is shown in Fig. 6. A good model fit is obtained and both seasonal and storm events were simulated satisfactorily.

An identical parameter set, with adjustment made for
Table 2. Parameter values used for the Hore clear-felling simulation

\begin{tabular}{ll}
\hline Year & $\begin{array}{l}\text { Forest felled and replanted } \\
\text { Uptake rate parameter value } \\
\left(\mathrm{kg}-\mathrm{N} \mathrm{ha^{-1 } \text { day }}\right)\end{array}$ \\
\hline 1990 & 0.02 \\
1991 & 0.03 \\
1992 & 0.08 \\
1993 & 0.25 \\
1994 & 0.35 \\
\hline
\end{tabular}

appropriate changes in land-use and catchment area, is used to simulate nitrogen dynamics for the Afon Hore. However, to account for the felling-induced changes in the stream chemistry for the Hore, a new land-use class has been created for the recently felled area in the Hore. Also, for the Hore

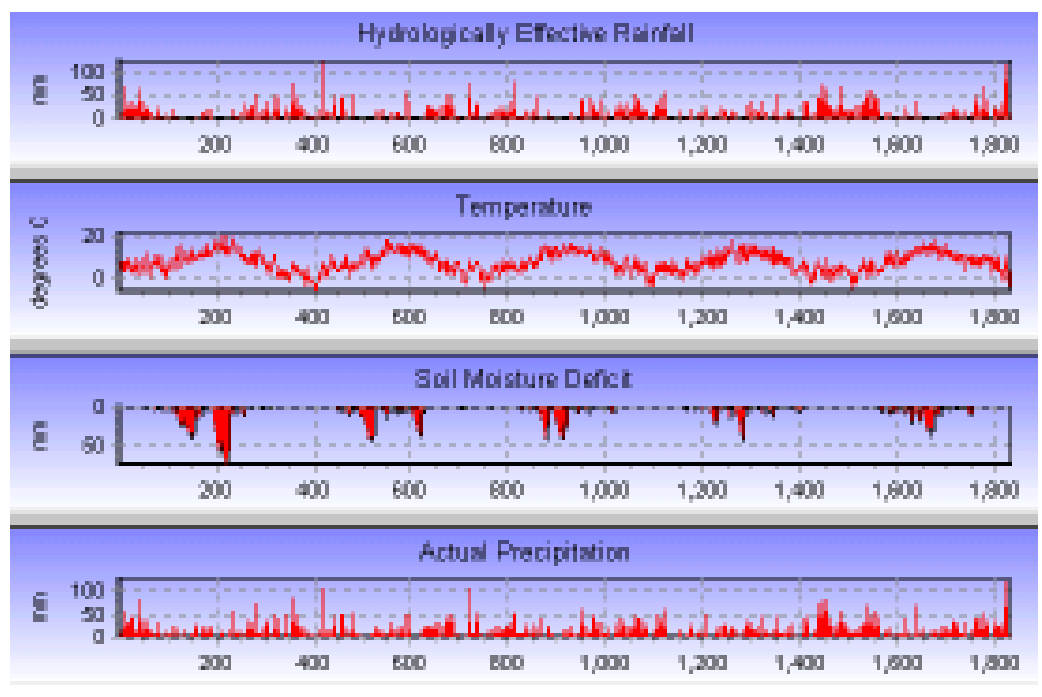

Fig. 5. The daily inputs for the Hafren sub-catchment from 1990-1994

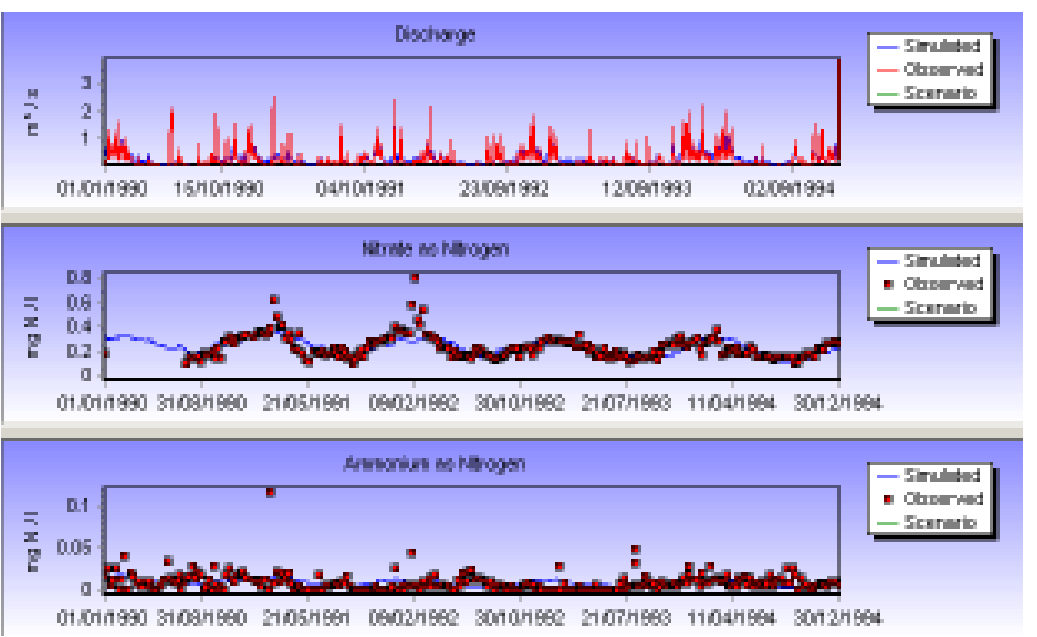

Fig. 6. The Hafren simulation for the years 1990-1994 
Table 3. Simulated Total $\mathrm{N}$ derived from different land-uses and catchments.

All values expressed as total nitrogen, with units in the form $\mathrm{kg} \mathrm{N} \mathrm{ha}^{-1} \mathrm{yr}^{-1}$

\begin{tabular}{llllllll}
\hline Year & & \multirow{2}{*}{ Hore } & & \multicolumn{2}{c}{ Hafren } & \multicolumn{2}{c}{ Total Output } \\
& Forest & Grass & Felled Forest & Forest & Grass & Hore & Hafren \\
\hline 1990 & 5.4 & 6.7 & 20.8 & 5.5 & 6.7 & 22 & 12 \\
1991 & 5.2 & 6.4 & 12.4 & 5.3 & 6.3 & 16 & 12 \\
1992 & 5.9 & 7.3 & 13.6 & 6.0 & 7.3 & 18 & 13 \\
1993 & 5.4 & 6.6 & 7.3 & 5.5 & 6.6 & 13 & 12 \\
1994 & 6.4 & 7.9 & 8.6 & 6.5 & 7.9 & 15 & 14 \\
\hline
\end{tabular}

simulations, the pre- and post-felling $\mathrm{N}$ uptake rates are set at different levels. Immediately after felling, uptake rates are minimal $\left(0.02 \mathrm{~kg} \mathrm{ha}^{-1}\right.$ day $^{-1}$ i.e. the same value for the Hafren) due to the large loss of vegetation cover. Postfelling, as replanting and natural vegetation growth commence, re-growth uptake rates increase until the values return to 'normal' post-felling rates. The full parameter set is described in Table 2.

Using these values, the model was adjusted to simulate the nitrogen chemistry for the Lower Hore streamwater chemistry. The modelling of clear felling enables the total annual loads for the nitrogen and ammonium species to be estimated for each of the different land-use categories. Table 3 shows the total nitrogen load released from each land-use category for each year simulated. For ease of comparison, and since the ammonium component is relatively small, nitrate and ammonium concentrations are combined to create total $\mathrm{N}$ values for each land-use. For 1990, the felled area of the Hore catchment contributes approximately four times the amount of total nitrogen to the river. As the uptake of nitrogen by the biomass increases, the felled area contributes similar amounts to established forest and outputs from the Hore post-felling return to levels similar to those found in the Hafren.

\section{Application to the Bedford Ouse}

The Great Ouse River System in eastern England (Fig. 7) has a catchment of $8380 \mathrm{~km}^{2}$ : it includes most of Cambridgeshire and Bedfordshire and parts of seven other counties. Two major river systems, the Bedford Ouse and the Ely Ouse, converge at Denver in Norfolk and transport

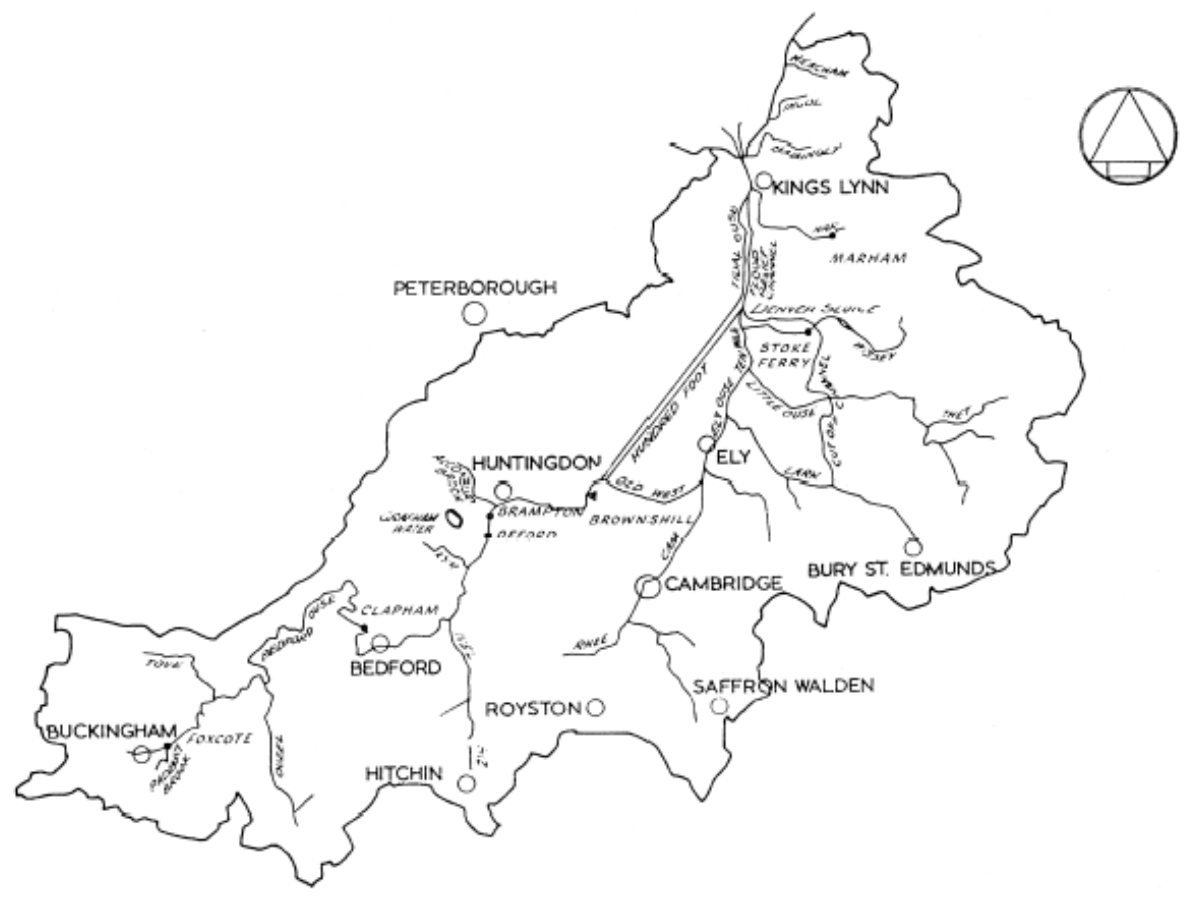

Fig. 7. The Bedford Ouse catchment in south-eastern England 
an average of $38.5 \mathrm{~m}^{3} \mathrm{~s}^{-1}$ of freshwater into the Great Ouse estuary and The Wash at King's Lynn. The population living in the catchment, approximately 1.6 million, results in very high levels of effluent discharge. Within the catchment there are over 500 sewage and industrial treatment plants, including those serving the major conurbations of Milton Keynes, Cambridge, Bedford and King's Lynn.

This study is concerned with the Bedford Ouse river system. It rises to the north of Brackley and flows northeastwards across the Oolitic and Cornbrash Limestones to Newport Pagnell, where the geology becomes impermeable clays (Ampthill, Kimmeridge and Oxford) which persist until Offord where chalk predominates. The river continues to flow north-eastwards to Brownshill Staunch which forms the downstream boundary of the Bedford Ouse river system in this study. Land-use in the Bedford Ouse catchment is mostly arable but with large urban centres at Milton Keynes and Bedford. The general water quality of the Bedford Ouse has been described by Neal et al. (2000).

Figure 8 shows the model reach structure selected for the Bedford Ouse and the location of the major effluent discharges. Table 4 shows this reach structure together with information on reach length, sub-catchment area and the land-use percentages obtained from the GIS-INCA interface. Reach boundaries for the river system are selected at the confluence of tributaries, at the location of effluent discharges, at weirs and at locations of water quality and flow monitoring stations, thereby allowing model simulations to be compared to observations at specific sites down the river.

Eight major sewage treatment works (STW) discharge into the Bedford Ouse between its source and Brownshill Staunch. Velocity discharge information for the Bedford Ouse has been derived from a set of tracer experiments conducted by Whitehead et al., (1986a). The following relationship has been derived from the field data.

$$
\mathrm{V}=0.046 \mathrm{Q}^{0.64}
$$

The base flow index (BFI) for the Bedford Ouse, obtained from the CEH Hydrometric Register and Statistics year book, averages 0.5 with a range of 0.48 to 0.55 . The Bedford Ouse model calibration is described by Whitehead et al. (1998b). In the present application, the model has been applied using the same parameter set but to recent data for the years 2000, 2001 and 2002. The input HER, soil moisture
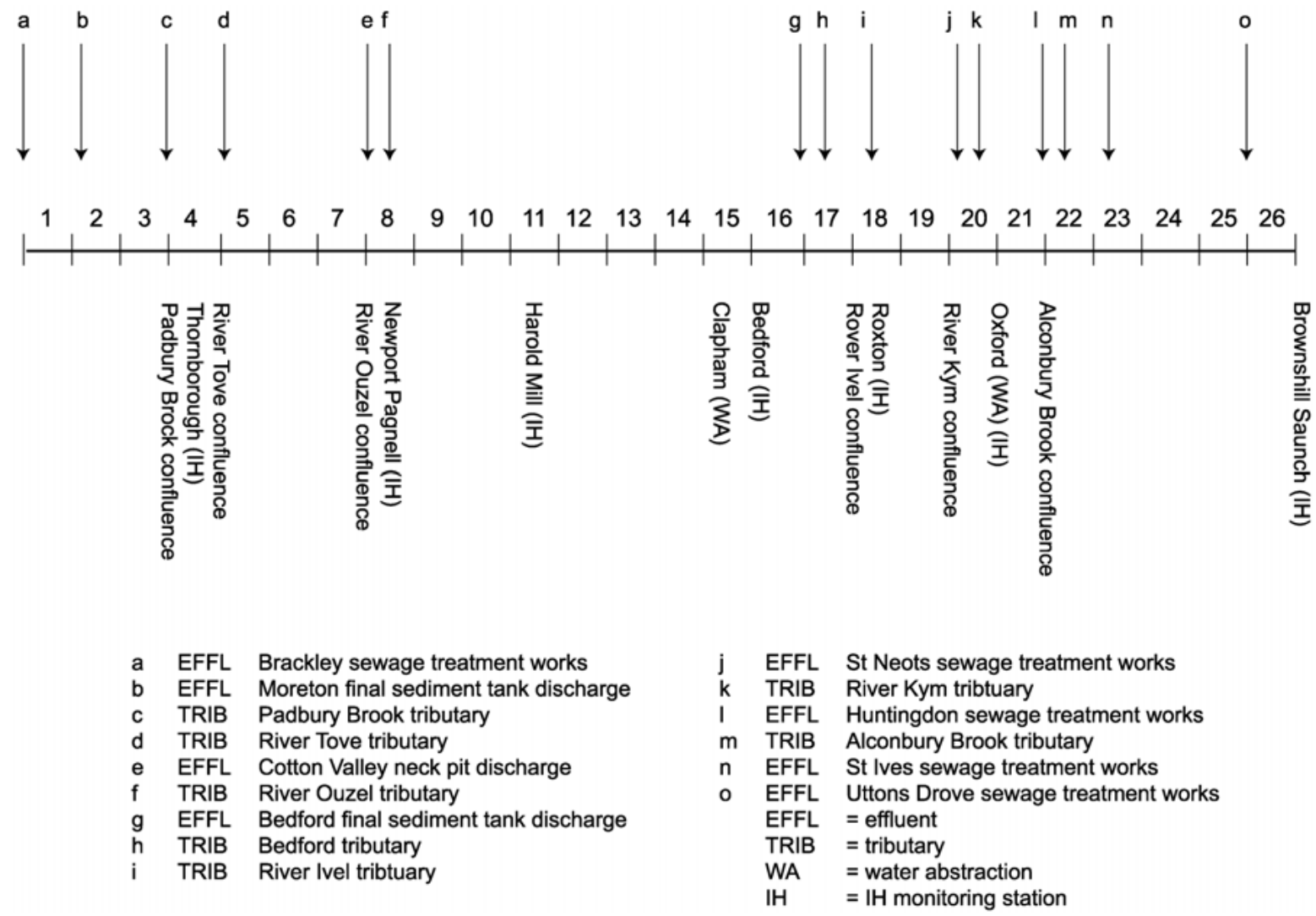

Fig. 8. The reach structure and effluent discharges on the Bedford Ouse 
Table 4. Reach and land-use information for the Bedford Ouse

\begin{tabular}{|c|c|c|c|c|c|c|c|c|}
\hline $\begin{array}{l}\text { Reach } \\
\text { number }\end{array}$ & $\begin{array}{c}\text { Reach length } \\
m\end{array}$ & $\begin{array}{l}\text { Area } \\
\mathrm{km}^{2}\end{array}$ & $\begin{array}{c}\text { Forest } \\
\%\end{array}$ & $\begin{array}{c}\text { SvegUG } \\
\%\end{array}$ & $\begin{array}{l}\text { SvegGNF } \\
\%\end{array}$ & $\begin{array}{l}\text { SvegF } \\
\%\end{array}$ & $\begin{array}{c}\text { Arable } \\
\%\end{array}$ & $\begin{array}{c}\text { Urban } \\
\%\end{array}$ \\
\hline 1 & 17750 & 102 & 3 & 0 & 11 & 10 & 75 & 1 \\
\hline 2 & 10000 & 51 & 0 & 0 & 20 & 15 & 59 & 6 \\
\hline 3 & 1250 & 238 & 1 & 0 & 17 & 20 & 62 & 0 \\
\hline 4 & 6500 & 56 & 4 & 0 & 12 & 13 & 71 & 0 \\
\hline 5 & 6500 & 290 & 4 & 0 & 7 & 7 & 81 & 0 \\
\hline 6 & 6500 & 50 & 0 & 0 & 24 & 2 & 42 & 22 \\
\hline 7 & 6000 & 384 & 2 & 0 & 16 & 3 & 71 & 8 \\
\hline 8 & 9250 & 74 & 1 & 0 & 10 & 0 & 88 & 1 \\
\hline 9 & 5500 & 37 & 0 & 0 & 10 & 3 & 84 & 3 \\
\hline 10 & 8000 & 33 & 0 & 0 & 9 & 0 & 91 & 0 \\
\hline 11 & 7000 & 31 & 0 & 0 & 0 & 0 & 100 & 0 \\
\hline 12 & 7000 & 30 & 0 & 0 & 10 & 0 & 90 & 0 \\
\hline 13 & 7000 & 15 & 0 & 0 & 0 & 0 & 100 & 0 \\
\hline 14 & 7000 & 14 & 0 & 0 & 0 & 0 & 100 & 0 \\
\hline 15 & 10000 & 66 & 0 & 0 & 9 & 0 & 80 & 11 \\
\hline 16 & 3750 & 12 & 0 & 0 & 17 & 0 & 0 & 83 \\
\hline 17 & 4500 & 147 & 0 & 0 & 7 & 1 & 85 & 7 \\
\hline 18 & 6750 & 577 & 1 & 0 & 7 & 1 & 83 & 8 \\
\hline 19 & 9500 & 325 & 1 & 0 & 5 & 1 & 91 & 2 \\
\hline 20 & 6250 & 34 & 0 & 0 & 3 & 0 & 94 & 3 \\
\hline 21 & 5750 & 36 & 0 & 0 & 3 & 0 & 94 & 3 \\
\hline 22 & 4000 & 13 & 0 & 0 & 8 & 0 & 77 & 15 \\
\hline 23 & 7000 & 251 & 0 & 0 & 6 & 3 & 88 & 3 \\
\hline 24 & 2750 & 91 & 0 & 0 & 7 & 1 & 91 & 1 \\
\hline 25 & 2500 & 38 & 0 & 5 & 11 & 0 & 84 & 0 \\
\hline 26 & 2000 & 1 & 0 & 0 & 0 & 0 & 100 & 0 \\
\hline
\end{tabular}

deficit and temperature data are shown in Figs. 9 and 10 with a comparison of the simulated and observed behaviour. This close match is reproduced down the river at all the flow gauges and water quality sampling stations, suggesting that INCA provides a good representation of the catchment.

The effects of future afforestation of the Bedford Ouse catchment have been assessed by INCA on the assumption of a possible change of $20 \%$ of the arable land to forest. Of course, many combinations of land-use change could be investigated with high levels of afforestation in certain subcatchments. The results show that there would be a substantial reduction in $\mathrm{NO}_{3}^{-}$concentrations in the river not only in the time series (Fig. 11) but right along the river system profile (Fig. 12). Afforestation is predicted to reduce the mean nitrate concentration at Bedford from 7.43 to $5.95 \mathrm{mg}-\mathrm{N} \mathrm{l}^{-1}$. While this may not seem a large change in the mean, the change in the 95 percentile level is a drop

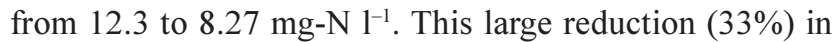
the 95 percentile level and effectively means that the nitrate levels would be well below the EU limits of potability of
$11.3 \mathrm{mg}-\mathrm{N}^{-1}$. Hence, $20 \%$ afforestation would have a major beneficial effect on the water quality from the viewpoint of a potable supply. Clearly, larger areas of forest would improve the water quality even more.

\section{Discusion and conclusions}

The INCA model has been applied to upland and lowland catchments to evaluate the impacts of afforestation on stream water quality. As the model is dynamic and semi-distributed in structure, it is able to simulate the effects of land-use change. The effects of clear-felling in the Hore catchment are simulated by reducing the vegetation uptake to zero and then gradually increasing it until uptake rates are 'normal'. For both the Hore and the Hafren catchments, peak nitrate and ammonium concentrations occur during the winter months, with a strong relationship between the patterns found at the upper and lower sites. After felling in the Hore catchment, there is a slight phase shift in the seasonal patterns in nitrate, although the most dominant feature is 


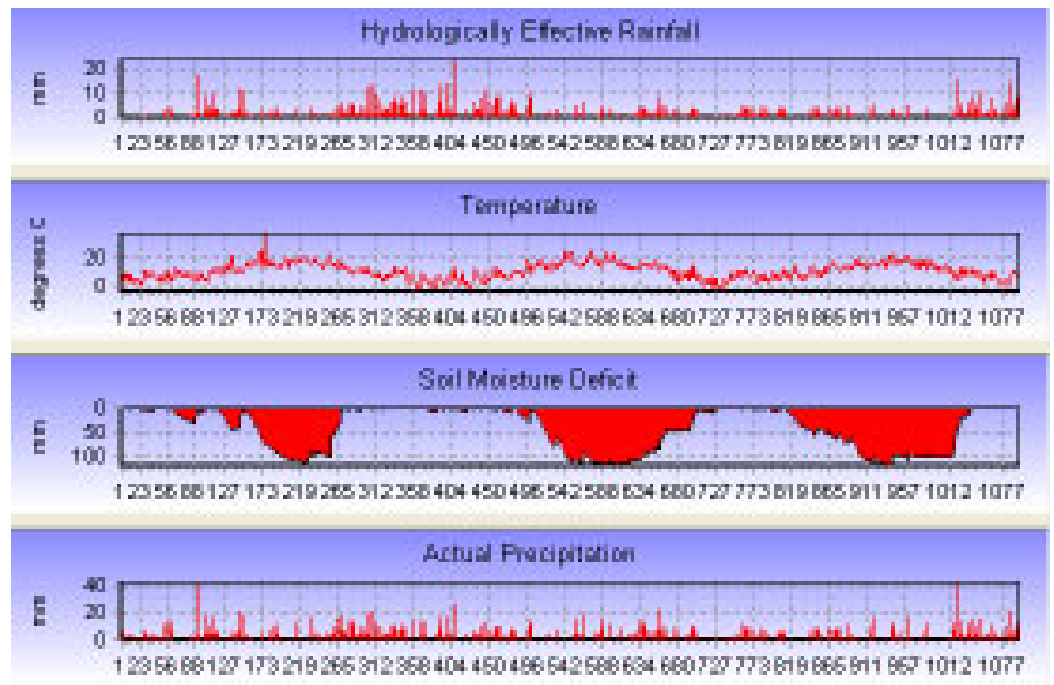

Fig. 9. HER, temperature and SMD data for the Bedford Ouse Catchment 2000-2002

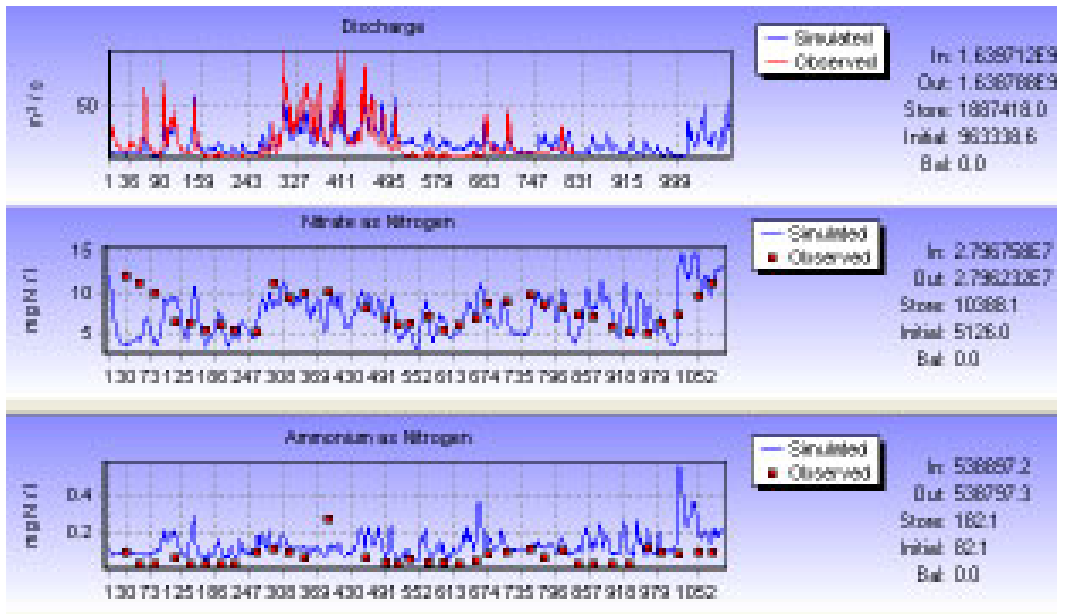

Fig. 10. Simulated and observed (in red) flow at Reach 15, nitrate and ammonium at Reach 26 on the Bedford Ouse

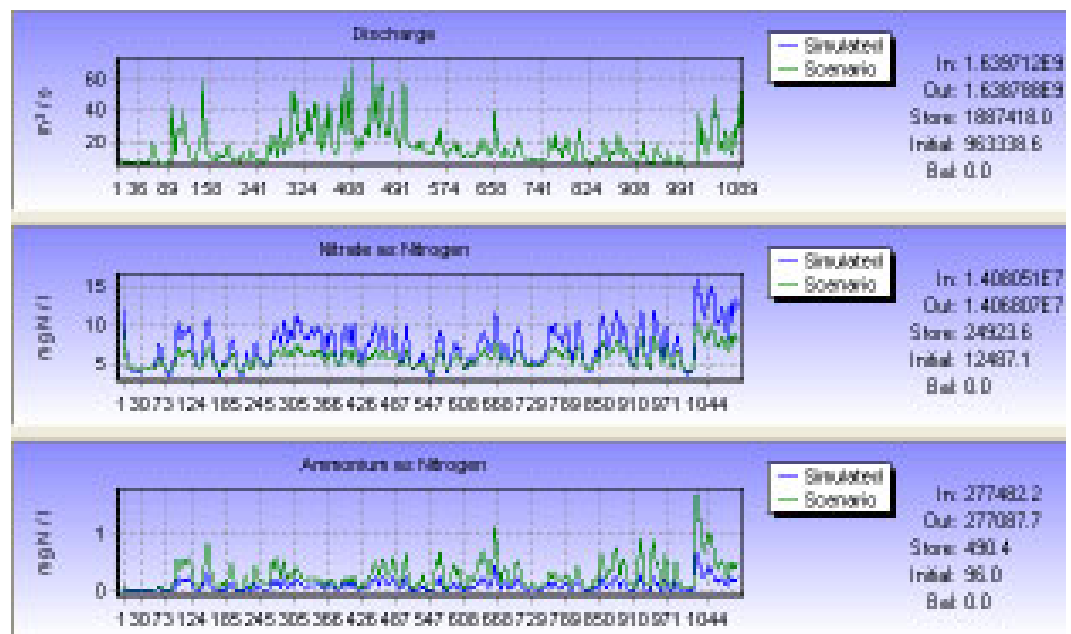

Fig. 11. Bedford Ouse baseline (blue) and scenario simulation (green) showing effect of $20 \%$ afforestation. 


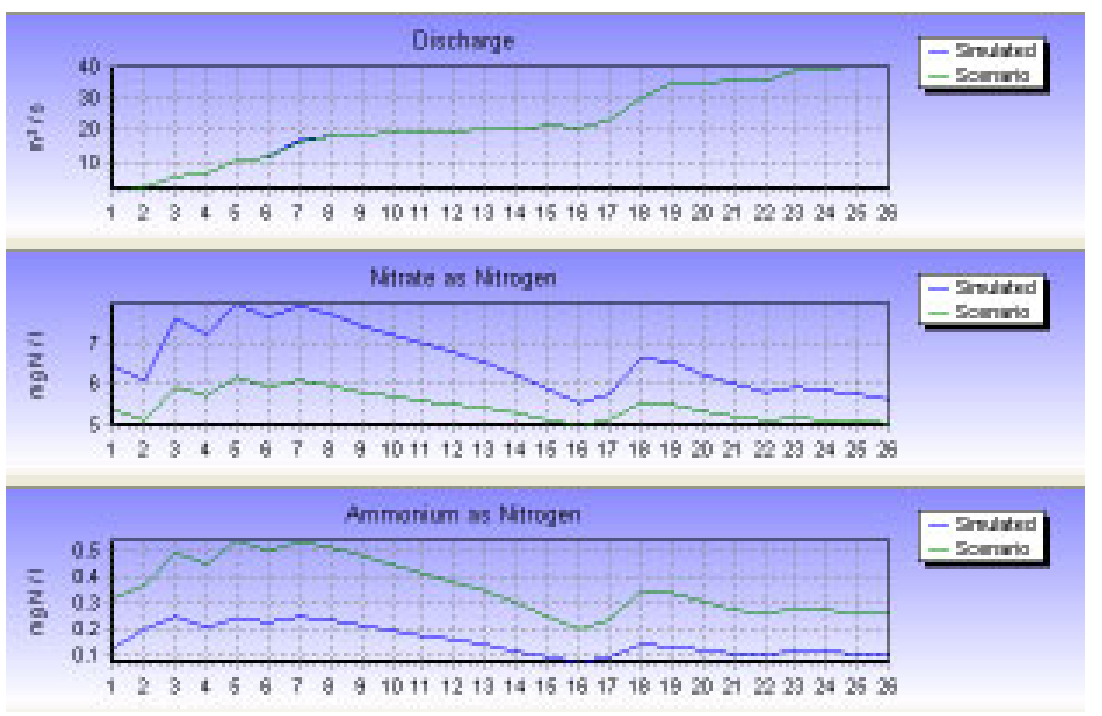

Fig. 12. Baseline (blue) and scenario simulation (green) for impacts of $20 \%$ afforestation on the nitrate profile along the Bedford Ouse.

the doubling of nitrate concentration. Nevertheless, the levels are still relatively low, well below the maximum allowed in drinking water $\left(11.3 \mathrm{mg}-\mathrm{N}^{-1}\right)$. The increased nitrate concentrations in the Hore, associated with felling are simulated by the model, although estimates of vegetative uptake rates are required to achieve this. Using this simulation and these estimates, the nitrate concentrations return to pre-felling concentrations several years after the commencement of felling. Discrepancies between observed and modelled output for the Plynlimon catchments are observed when the time series are examined in detail. However, the model simulations are surprisingly good given that, except for uptake parameter which simply reflects the increasing tree growth, the same model parameter set is used for both catchments. Indeed, the INCA approach yields not only a very good representation of stream chemistry but better results than models operating on a more complex basis such as with a fully distributed representation or with more complex chemical representation.

The Bedford Ouse catchment is of a very different order of magnitude in terms of size and complexity compared to small upland catchments. The Bedford Ouse catchment has a large number of discharges from tributaries and effluents and the land-use is predominantly arable farming, with major inputs of $\mathrm{N}$ from diffuse sources. Despite this higher level of complexity, INCA is still able to reproduce satisfactorily the hydrological and nitrogen response of the system. This, in itself, is a major achievement and supports the long held view that a law of large systems applies to the catchment systems (Young, 1978), whereby large complex systems can be represented by relatively low order models. Recently, fractals have been shown to play a role in catchment behaviour patterns (Kirchner et al., 2000, 2001; Neal and Kirchner, 2000). How the fractal processes can be combined with process understanding and chemical transformation is an active area of interest and well worthy of considerable study.

The notional impact of $20 \%$ afforestation on the water quality of the Bedford Ouse is significant in the INCA simulation; a $12 \%$ fall in the mean level of nitrate-N in the river leads to a $33 \%$ fall in the 95 percentile level. This reduction in the 95 percentile level is highly significant because of the EU limits of $11.3 \mathrm{mg}-\mathrm{N} \mathrm{l}^{-1}$ on drinking water supply. The INCA simulation suggests that a $20 \%$ increase in forest in the catchment would have a beneficial impact on stream water quality and, hence, would protect water supplies in the Bedford Ouse from a nitrate-N viewpoint. Clearly larger increases in afforestation would have an even more beneficial effect.

\section{Acknowledgements}

The authors are particularly grateful to the CEH hydrochemistry group for provision of chemical data for Plynlimon.

\section{References}

Cosby, B.J., Hornberger, G.M. and Galloway, J.N., 1985 a. Modelling the effects of acid deposition: assessment of a lumped parameter model of soil water and streamwater chemistry. Water Resour. Res., 21, 51-63. 
Cosby, B.J., Wright, R.F., Hornberger, G.M. and Galloway, J.N. 1985b. Modelling the effects of acid deposition estimation of the long term water quality responses in a small forested catchment. Water Resour. Res., 21. 1591-1601.

Dise, N.B. and Wright, R.F., 1995. Nitrogen leaching from European forests in relation to nitrogen deposition. Forest Ecol. Manage., 71, 153-161.

Flynn, N.J., Paddison, T. and Whitehead, P.G., 2002. INCA modelling of the Lee system: strategies for the reduction of nitrogen loads. Hydrol. Earth Syst. Sci., 6, 467-485.

Forti, M.C., Neal, C. and Robson, A.J., 1996. Modelling the longterm changes in stream, soil and groundwater chemistry for an acid moorland in the Welsh uplands: the influence of variations in chemical weathering. Sci. Total Envir., 180, 187-200.

Jarvie, H.P., Wade, A.J., Butterfield, D., Whitehead, P.G., Tindall, C.I. Virtue, W.A., Dryburgh, W. and McGraw, A., 2002. Modelling nitrogen dynamics and distributions in the River Tweed, Scotland: an application of the INCA model. Hydrol. Earth Syst. Sci., 6, 297-615

Kirchner, J.W., Feng, X.H. and Neal, C., 2000. Fractal stream chemistry and its implications for contaminant transport in catchments. Nature, 403, 524-527.

Kirchner, J.W., Feng, X.H. and Neal, C., 2001. Catchment-scale advection and dispersion as a mechanism for fractal scaling in stream tracer concentrations. J. Hydrol., 254, 81-100.

Lee, D.S., Kingdon, R.D., Jenkin, M.E. and Garland, J.A., 2000. Modelling oxidised and reduced nitrogen budgets for the UK with a Lagrangian multi-layered long-range transport model. Envir. Mod. Assess., 5, 83-104.

Metcalfe, S.E., Whyatt, J.D. and Derwent, R.G., 1998. Multipollutant modelling and critical loads approach for nitrogen. Atmos. Envir., 32, 401-408.

Neal, C (Ed.), 2002a. Assessing nitrogen dynamics in catchments across Europe within an INCA modelling framework. Hydrol. Earth Syst. Sci., 6, 297-616.

Neal, C., 2002b. Nutrient concentrations and fluxes for podzolic and gley soils at Plynlimon, mid-Wales: implications for modelling inorganic nitrogen and phosphorus in upland UK environments. Hydrol. Earth Syst. Sci., 6, 403-420.

Neal, C. and Kirchner, J.W., 2000. Sodium and chloride levels in rainfall, mist, streamwater and groundwater at the Plynlimon catchments, mid-Wales: inferences on hydrological and chemical controls. Hydrol. Earth Syst. Sci., 4, 295-310.

Neal, C., Robson, A.J., Reynolds, B. and Jenkins, A., 1992 b. Prediction of future short- term stream chemistry - a modelling approach. J. Hydrol., 130, 87-103.

Neal, C., Wilkinson, J., Neal, M., Wickham, H., Hill, L. and Morfitt, C., 1997. The hydrochemistry of the headwaters of the River Severn, Plynlimon. Hydrol. Earth Syst. Sci., 1, 583-617.

Neal, C., Jarvie, H.P., Williams, R.J., Pinder, L.C.V., Collett, G.D., Neal, M. and Bhardwaj, L., 2000. The water quality of the Great Ouse. Sci. Total Environ., 251/252, 423-440.

Neal, C., Reynolds, B., Neal, M., Hill, L., Wickham, H. and Pugh, B., 2003. Nitrogen in rainfall, cloud water, throughfall, stemflow, stream water and groundwater for the Plynlimon catchments of mid-Wales. Sci. Total Envir., 314/315/316, 121-152.

Raat, .J., Draaijers, G.P.J., Schaap, M.G., Tietma, A. and Verstraten, J.M., 2002. Spatial variability of throughfall water and chemistry and forest floor water content in a Douglas Fir stand. Hydrol. Earth Syst. Sci., 3, 363-374.

Reid, J.M., MacLeod, D. A. and Cresser, M.S., 1981. Factors affecting the chemistry of precipitation and river water in an upland catchment. J. Hydrol., 50, 129-145.

Reynolds, B., Neal, C., Hornung, M., Hughes, S. and Stevens, P. A., 1988. Impact of afforestation on the soil solution chemistry of stagnopodzols in Mid-Wales. Water Air Soil Pollut., 38, 55-70.
Reynolds, B., Emmett, B.A. and Woods, C., 1992. Variations in streamwater nitrate concentrations and nitrogen budgets over 10 years in a headwater catchment in mid- Wales. J. Hydrol., 136, 155-175.

Robson, A.J., Jenkins, A. and Neal, C., 1991. Towards predicting future episodic changes in stream chemistry. J. Hydrol., 125 , 161-174.

Skeffington, R., 2002, European nitrogen policies, nitrate in rivers and the INCA model. Hydrol. Earth Syst. Sci., 6,315-324.

Stevens, P. A., Norris, D. A., Sparks, T. H. and Hodgson, A. L., 1994. The impacts of atmospheric N inputs on throughfall, soil and stream water interactions for different aged forest and moorland catchments in Wales. Water Air Soil Pollut., 73, 297317.

Wade, A.J., Soulsby,C., Langan, S.J., Whitehead, P.G., Edwards, A.C., Butterfield, D., Smart, M., Cook, Y. and Owen, R.P., 2001. Modelling instream nitrogen variability in the Dee catchment. Sci. Total Envir., 265, 229-252.

Wade, A.J., Durand, P., Beaujouan, V., Wessel, V.W., Raat K.J., Whitehead, P.G., Butterfield, D., Rankinen, K., and Lepisto, A., 2002. A nitrogen model for European catchments: INCA, new model structure and equations. Hydrol. Earth Syst. Sci., 6, 559-583.

Whitehead, P.G., Williams, R. and Hornberger, G.E., 1986a. On the identification of pollutant on tracer sources using dispersion theory. J. Hydrol., 84, 273-286.

Whitehead, P.G., Neal, C. and Neale, R., 1986b Modelling the effects of hydrological changes on stream acidity. J. Hydrol., 84, 353-364.

Whitehead, P.G., Bird, S., Hornung, M., Cosby, B.J. and Paricos, P. 1988a. Stream acidification trends in the Welsh uplands: A modelling study of the Llyn Brianne catchment. J. Hydrol., 101, 191-212.

Whitehead, P.G., Reynolds, B., Hornung, M., Neal, C., Cosby, J and Paricos, P., 1988b. Modelling long term stream acidification trends in upland Wales at Plynlimon. Hydrol. Process., 2, 357 368.

Whitehead, P.G., Wilson, E.J. and Butterfield, D., 1998a. A semidistributed Integrated Nitrogen model for multiple soiurce in Catchments (INCA): Part I - model structure and process equation. Sci. Total Envir., 210/211, 547-558.

Whitehead, P.G., Wilson, E.J., Butterfield, D. and Seed, K., 1998b. A semi-distributed Integrated Nitrogen model for multiple source in Catchments (INCA) Part II: application to large river basins in South Wales and Eastern England. Sci. Total Envir., 210/211, 559-583.

Whitehead, P.G., Johnes, P.J. and Butterfield, D., 2002 Steady state and dynamic modelling of nitrogen in the River Kennet: impacts of land-use change since the 1930s. Sci. Total. Envir., 282-283, $417-435$.

Wilkinson, R.J., Reynolds, B., Neal, C., Hill, S., Neal, M. and Harrow, M.L., 1997. Major, minor and trace element composition of cloud water and rain water at Plynlimon, MidWales. Hydrol. Earth Syst. Sci., 1, 557-570.

Wilson, E.J. and Emmett, B.A., 1999. Factors influencing nitrogen saturation in forest ecosystems: advances in our understanding since the mid 1980s. In: The impact of nitrogen deposition on natural and semi-natural ecosystems, S.J. Langan, (Ed.). Vol. 3 of Series on Environmental Pollution. Kluwer, The Netherlands. 123-152.

Young, P.C., 1978 A general theory of modeling for badly defined dynamic systems. In: Modeling, Identification and Control in Environmental Systems, G.C. Vansteenkiste (Ed.), North Holland, Amsterdam, The Netherlands. 103-135. 